\title{
PENINGKATAN PELAYANAN RUMAH SAKIT PEMERINTAH MELALUI ANALISIS EMPATI DAN MOTIF ALTRUISTIK PERAWAT DI SUMATERA BARAT
}

\author{
Firman Firman.
}

\author{
Jurusan Bimbingan dan Konseling Universitas Negeri Padang \\ Email : firman@konselor@org
}

\begin{abstract}
ABSTRAK
Penelitian ini bertujuan mengungkapkan empati dan motif altuistik perawat dalam pemberian pelayanan terhadap pasien di rumah sakit pemerintah Propinsi Sumatera Barat. Penelitian ini dilaksanakan melalui survey. Populasi penelitian ini adalah perawat yang bertugas di rumah sakit pemerintah Propinsi Sumatera Barat, dengan karakteristik pegawai negeri dengan golongan II sampai dengan IV dan terlibat langsung dalam pemberian pelayanan terhadap pasien di rumah sakit. Pengambilan sampel menggunakan teknik Stratified Random Sampling. Data dikumpulkan dengan kuessioner dan. pengolahan data menggunakan persentase serta analisis regresi. Berdasarkan hasil penelitian ditemukan : (1) perawat dalam pemberian pelayanan di rumah sakit belum berempati terhadap permasalahan pasien secara optimal, (2) perawat dalam memberi pelayanan di rumah sakit terhadap pasien belum memiliki motif altruistik secara optimal serta (3) terdapat pengaruh empati terhadap motif altruistik perawat di rumah sakit dalam pemberian pelayanan.
\end{abstract}

\section{A. Pendahuluan}

Pembangunan kesehatan di Indonesia ditujukan untuk mercapai kesadaran, kemauan dan kemampuan hidup sehat bagi setiap penduduk agar dapat mewujudkan derajat kesehatan yang lebih tinggi. Gambaran masyarakat Indonesia masa depan yang ingin dicapai melalui pembangunan kesehatan adalah masyarakat, bangsa dan negara ditandai oleh penduduknya yang hidup dalam lingkungan dengan perilaku hidup sehat, memiliki kemampuan menjangkau pelayanan kesehatan setinggi-tingginya (Indonesia Sehat 2010, 1999).

Pemerataan dan peningkatan mutu pelayanan kesehatan sebagai sasaran utama pembangunan kesehatan ditentukan oleh ketersedia Sumber Daya Manusia yang memadai dalam mewujudkan kesempurnaan pelayanan menuju kepuasan pasien. Rumah Sakit merupakan suatu organisasi yang multi kompleks, selain padat modal dan karya, teknologi serta profesi, memerlukan manajemen secara khusus dalam peningkatan pelayanan. Setiap rumah sakit dituntut mengembangkan kemampuan meningkatkan mutu pelayanan dalam menghadapi persaingan global. Persaingan global di bidang kesehatan mengakibatkan kompetisi meningkat tajam, nilai bagi pelanggan cepat sekali berubah, baik karena tuntutan kebutuhan maupun persaingan secara inovatif dalam menawarkan jasa yang lebih bermanfaat.

Keberhasilan pelayanan rumah sakit salah satu hal ditentukan oleh terpenuhinya kepuasan pasien. Strategi yang berfokus kepada kepuasan pasien sebagai pelanggan 
merupakan rencana bisnis dalam menawarkan karakteristik jasa, atribut, serta pelaksanaannya sesuai dengan kebutuhan pasien. Dalam lingkungan bisnis pelanggan memegang kendali, suara pelanggan harus selalu didengarkan agar rumah sakit mampu menghasilkan jasa yang bernilai bagi masyarakat pelanggan rumah sakit tersebut.

Paradigma baru yang berkembang dalam manajemen rumah sakit untuk menghadapi lingkungan bisnis global maupun domestik adalah strategi yang berfokus pada kepuasan pelanggan, pelayanan yang berkualitas, peningkatan dan pengembangan terus menerus, serta sistem pengorganisasian yang sesuai. Paradigma demikian untuk rumah sakit dijabarkan sebagai pelayanan prima rumah sakit. Pewujudan pelayanan prima, rumah sakit bertugas melaksanakan upaya kesehatan secara berdaya guna dan berhasil guna dengan mengutamakan penyembuhan dan pemulihan yang dilaksanakan secara serasi dan terpadu dengan upaya peningkatan dan pencegahan serta melaksanakan upaya rujukan (SK Menteri Kesehatan RI No.542/MENKES/SK/VI/1994). Upaya lain pemerintah dalam meningkatkan mutu pelayanan rumah sakit adalah menetapkan rumah sakit pemerintah sebagai rumah sakit swadana.

Salah satu faktor penentu pelayanan rumah sakit adalah kualitas pelayanan yang diberikan perawat. Perawat adalah satu jenis profesi yang dewasa ini dibutuhkan dan diusahakan peningkatan kualitas keprofesiannya. Tugas pokok seorang perawat adalah merawat pasien untuk mempercepat proses penyembuhan. Dalam menghadapi pasien seorang perawat membutuhkan keterampilan-keterampilan tertentu yang dipelajari sebelumnya di bangku pendidikan.

Gunarsa dan Gunarsa (1985) menjelaskan seorang perawan telah dipersiapkan melalui pendidikan untuk turut serta merawat dan menyembuhkan orang sakit, usaha rehabilitasi, pencegahan penyakit yang dilaksanakan sendiri atau di bawah pengawasan dokter atau suster kepala. Sehubungan dengan hal itu, cakupan kerja seorang perawat cukup luas, tidak hanya merawat tetapi sampai pada tindakan rehabilitasi yang membutuhkan persyaratan-persyaratan tertentu.

Keberhasilan perawan dalam memberikan pelayanan kesehatan ditentukan oleh cara berinteraksi dengan pasien. Hubungan yang mencerminkan adanya kebaikan, belas kasihan, tengang rasa, kelembutan hati, cinta, perhatian, keharuan, kerjasama, tanggapan dan kepeduliaan semakin menambah makna pelayanan yang diberikan kepada pasien. Smart dan Smart (1980:275) menjelaskan sikap baik hati dan suka menolong merupakan hal yang alami dan manusiawi, sebagaimana halnya sikap egois dan agresif pada manusia.

Pertolongan yang diberikan perawat kepada pasien tidak lepas dari motif yang berorientasi pada diri sendiri (motif egoistik). Tuntututan tugas perawat mengharuskan untuk tidak mementingkan diri sendiri tetapi memperhatikan kebutuhan orang lain (motif altruistik). Motif altristik merupakan pertolongan yang semata-mata berorientasi kepada kebutuhan 
pasien yang membutuhkan dan perawat memperoleh kebahagiaan tersendiri atas tindakan tersebut. Kebahagiaan yang dialami perawat tersebut dapat mendorong terjadinya perilaku altruistik yang lain, sehingga perilaku altruistik yang ada bisa melestarikan norma tolong menolong di lingkungan rumah sakit.

Berdasarkan pengamatan di rumah sakit ditemukan, tidak semua perawat yang bersedia memberikan pertolongan sesuai dengan kebutuhan pasien. Liebert (1979 : 320) menjelaskan faktor utama menentukan seseorang memberikan pertolongan adalah berempati terhadap orang yang membutuhkan pertolongan tersebut. Soelaeman (1992 :482) menjelaskan empati merupakan intisari dari motif-motif moral, sebab dapat mentransformasikan penderitaan orang lain menjadi ketidaknyamanan bagi diri sendiri, sehingga merasa bertanggung jawab atas keadaan yang tidak menyenangkan yang dialami orang lain.

Penelitian Coke, Batson dan McDavis (Brems, Fromme dan Johnson,1992:190) menjelaskan kemampuan untuk mengambil perspektif tentang orang yang membutuhkan pertolongan ternyata meningkatkan emosi empati. Selanjutnya hal ini berhubungan dengan perilaku menolong dan motif altruistik untuk menolong orang lain. Kondisi ini disebabkan motif dipandang sebagai kekuatan yang terdapat dalam diri organisme yang menyebabkan organisme tersebut bertindak.

Empati perawat dalam memberikan pelayanan terhadap pasien dewasa ini perlu mendapatkan perhatian dalam peningkatan kualitas pelayanan. Ohbuchi, Ohno dan Mukai (1993) menjelaskan pembangkit empati merupakan faktor situasional yang penting sehingga bisa menghambat agresi terhadap orang lain. Selain itu empati sudah lama dipandang sebagai suatu karakteristik penting yang merupakan domain yang ada pada ahli-ahli psikoterapi kompeten di bidangnya. Ahli tersebut menekankan pentingnya empati dalam memahami pasien (Greenson,1960). Di sisi lain ahli-ahli terapi humanistik meyakini bahwa empati merupakan kualitas terapis yang sangat penting dan turut menentukan hasil terapi (Truax dan Carkhuff dalam Brems, Fromme dan Johnson, 1992:189).

Perawat sebagai suatu pekerjaan profesi dicirikan oleh adanya suatu tuntutan untuk memiliki dasar ilmu pengetahuan dan keahlian yang khas dalam bidang keperawatan. Perawat selain memiliki pengetahuan yang berkaitan dengan lingkungan pekerjaannya juga menguasai ilmu tentan etika kerja yang harus diterapkan dalam tugas sehari-hari. Pemahaman atas penderitaan pasien serta bersedia menolong tanpa pamrih merupakan tuntutan tugas yang melekat pada profesi perawat di rumah sakit.

Berdasarkan hasil wawancara dengan beberapa pasien di salah satu rumah sakit pemerintah di Kota Padang, terungkap pelayanan yang diberikan perawat di rumah sakit jauh dari apa yang mereka harapkan. Perawat melaksanakan tugas apa adanya tanpa tuntutan produktifitas kinerja yang tinggi. Pekerjaan dalam perawatan kesehatan kepada pasien 
kadang-kadang diserahkan kepada mahasiswa Akademi Perawat yang sedang mencari pengalaman tanpa bimbingan langsung perawat senior. Begitu juga apabila pasien mau dirawat atau dioprasi, tidak jarang urusan yang dilalui keluarga pasien berbelit-belit. Koordinasi satu bagian dengan bagian lainnya belum menunjang kelancaran perawatan, sehingga pasien merasakan tidak mendapatkan perawatan dengan segera. Apabila pasien meminta pertolongan sehubungan dengan perawatan terhadap penyakit yang dideritanya, perawat kadang-kadang mengoceh atau memberikan pertolongan apa adanya. Pasien selama dirawat di rumah sakit gelisah dan takut apabila ditinggal oleh keluarga selama memperoleh perawatan. Penderitaan atas penyakit yang diderita pasien dan kegelisahan keluarga pasien selama menjalani perawatan di rumah sakit kurang mendapat tanggapan dari perawat. Tidak jarang pelayanan administratif yang berbelit-belit mempersulit pasien memperoleh perawatan. Perilaku ini mengakibatkan rasa tanggung jawab sangat kurang terhadap pekerjaan, keterlambatan dalam memperoleh pelayanan oleh pasien, kurang ramahnya petugas kesehatan, serta mahalnya senyum oleh petugas kesehatan. Komunikasi antara perawat dan pasien tidak berjalan lancar, karena pasien berada pada posisi yang lemah dan pasien sangat tergantung kepada perawat. Kondisi ini didukung dari kotak saran yang dikumpulkan sejak tahun 1997 sampai tahun 2001 sebanyak 120 lembar (sumber pusat informasi RSUP Dr. M. Djamil Padang), di samping kenyamanan ruangan serta komunikasi timbal balik dalam pelayanan yang kurang komunikatif, masalah ini akan menimbulkan ketidak puasan pasien dalam menerima pelayanan.

Bertitik tolokan dari uraian tersebut, terlihat pelayanan kesehatan yang diberikan perawat di rumah sakit ditentukan oleh motif altruistik dan empati perawat terhadap penderitaan yang dialami pasien. Sehubungan dengan hal itu, melalui penelitian ini menarik untuk ditelusuri lebih lanjut empati dan motif altruistik perawat terhadap pasien di rumah sakit. Pengungkapan empati dan motif altruistik perawat terhadap pasien bermanfaat untuk menunjang keahlian perawat dalam memahami serta sensitif terhadap penderitaan orang lain. Pada gilirannya kualitas pelayanan rumah sakit dapat ditingkatkan melalui perbaikan empati dan motif altruistik perawat terhadap pasien di rumah sakit

\section{B. Metode Penelitian}

Penelitian ini dilaksanakan melalui survey untuk mendeskripikan empati dan motif altruistik perawat dalam pemberian pelayanan di rumah sakit di Sumatera Barat. Populasi penelitian ini adalah perawat yang bertugas di rumah sakit pemerintah di Daerah Kabupaten/Kota Propinsi Sumatera Barat, dengan karakteristik pegawai negeri dengan golongan II sampai dengan IV dan terlibat langsung dalam pemberian pelayanan terhadap pasien di rumah sakit. Pengambilan sampel menggunakan teknik teknik Stratified Random 
Sampling. Data dikumpulkan dengan kuessioner dan. dianalisis dengan persentase dan analisis regresi.

\section{Hasil Penelitian dan Pembahasan}

\section{Empati Perawat terhadap Pasien di Rumah Sakit}

Empati perawat terhadap pasien dalam memberikan pelayanan di rumah sakit terlihat pada tabel berikut ini :

Tabel 1 : Empati Perawat terhadap Permasalahan yang Dialami Pasien di Rumah Sakit.

\begin{tabular}{|c|l|c|c|c|c|c|}
\hline No & \multicolumn{1}{|c|}{ INDIKATOR } & SS & SR & JR & JS & TP \\
\hline 1. & $\begin{array}{l}\text { Memahami } \\
\text { permasalahan } \\
\text { pasien. }\end{array}$ & $40.05 \%$ & $27.02 \%$ & $17.08 \%$ & $12.93 \%$ & $2.89 \%$ \\
\hline 2. & $\begin{array}{l}\text { Menempatkan diri } \\
\text { terhadap } \\
\text { permasalahan } \\
\text { pasien. }\end{array}$ & $22.42 \%$ & $48.53 \%$ & $14.49 \%$ & $11.15 \%$ & $3.39 \%$ \\
\hline & Jumlah & $20.31 \%$ & $46.51 \%$ & $18 \%$ & $11.69 \%$ & $3.46 \%$ \\
\hline
\end{tabular}

Berdasarkan tabel di atas diperoleh keterangan, sebanyak 40,05\% perawat yang bertugas di rumah sakit dalam memberikan pelayanan sangat sering memahami permasalahan yang dialami pasien. Selanjutnya sebnyak 27,02 \% sering , 17,08 jarang dan 2,89 \% tidak pernah memahami permasalahan yang dialami pasien dalam memberikan pelayanan perawatan di rumah sakit. Dengan demikian sebagian besar perawat di rumah sakit dalam memberikan pelayanan dapat memahami permasalahan yang dialami pasien. Walaupun demikian pemahaman terhadap permasalahan yang dialami pasien belum optimal dalam memberikan pelayanan di rumah sakit $(32,7 \%=17,08 \%$ jarang, 12,93\% jarang sekali dan 2,69 tidak pernah memahami permasalahan yang dialami pasien) .

Dari segi penempatan diri terhadap permasalahan yang dialami pasien, diperoleh keterangan sebanyak 40,53\% perawat mengungkapkan sering dapat menempatkan diri sesuai dengan permasalahan yang dialami pasein. Selanjutnya sebanyak $22,42 \%$ sering sekali, 14,49 jarang,11,15 jarang sekali dan 3,39 \% tidak pernah dapat menempatkan diiri 
sesuai dengan permasalahan yang dialami pasien. Dengan demikian sebagian besar perawat di rumah sakit sudah dapat menempatkan diri sesuai dengan permasalahan yang dalami pasien. Walaupun demikian penempatan diri perawat sesuai dengan permasalahan yang dialami pasien belum optimal $(29,03 \%=14,49 \%$ jarang, $11,15 \%$ jarang sekali dan 3,39 \% tidak pernah dapat menempatkan diri sesuai dengan permasalahan yang dialami pasien).

Berdasarkan tabel di atas, secara keseluruhan ditemukan sebanyak 46,51\% perawat dalam memberikan pelayanan di rumah sakit dapat berempati terhadap paseien. Selanjutnya 20,31 \% sangat sering, $18 \%$ jarang, 11,69 jarang sekali dan 3,46 \% tidak pernah berempati dalam memberikan pelayanan terhadap pasien. Dengan demikian sebagian besar perawat dalam memberikan peyanan di rumah sakit dapat berempati terhadap pasien. Walupun demikian empati perawat dalam memberikan pelayanan terhadap pasien belum optimal $(33,15$ $\%=18 \%$ jarang, $11,69 \%$ jarang sekali dan 3,46\% tidak pernah berempati terhadap pasien dalam memberikan pelayanan di rumah sakit).

Belum optimalnya empati perawat terhadap pasien diduga karena sebagian besar perawat yang bertugas di rumah sakit sudah bekerja selama 10 - 34 tahun sebagai perawat $(79,2 \%)$. Kondisi semacam ini menyebabkan kejenuhan dan tumpulnya kesensitifan terhadap permasalahan pasien. Peningkatan kesensitifan terhadap permasalahan orang lain ditentukan oleh sosialisasi melalui pelatihan dan penataran dalam peningkatan kinerja perawat.

Soelaiman (1992:482-484) menjelaskan sosialisasi dapat membentuk kecenderungan empatik atau egosentris individu. Individu dapat berempati dengan baik terhadap perasaan orang lain apabila telah mengalami perasaan tersebut. Sehubunan itu perkembangan empati sebaiknya dilakukan dengan mensosialisasikan pengalaman yang mengarahkan perhatian individu pada penderitaan orang lain. Topik-topik penataran yang diberikan kepada perawat yang menuju pemahan penderitaan orang lain dalam pelatihan dituntut untuk menumbuhkan empati terhadap pasien.

Pendekatan yang digunakan dalam pelatihan sangat menentukan dalam menumbuh empati perawat. Berdasarkan penelitian Staub Pares, (1984:567) mebuktikan anak-anak dari Taman Kanak-Kanak yang telah dilatih melalui role playing untuk memehami dan mengekspresikan perasaan yang sedang dirasakan orang lain serta menerima peran sebagai penolong, lebih sering merespon terhadap suara tangisan dibandingkan dengan anak-anak yang tidak dilatih. Umumnya anak perempuan lebih tinggi dapat mengembangkan rasa empati dibandingkan anak laki-laki.

Pembelajaran empati dapat dilakukan dengan memperlakukan perawat dengan baik didukung oleh suasana kerja yang kondusif, tersedianya contoh atas tindakan empati serta mengajarkan bagaimana perasaan orang lain. Kondisi semacam ini sangat diperlukan bagi calon-salon perawat yang sedang berpengalaman lapangan di rumah sakit. Apabila hubungan persahabatan antara perawat yunior dengan senior serta dengan mahasiswa yang sedang 
berpengalaman belum terwujud kondisi empati bagi perawat-perawat yunior tidak akan berkembang dengan baik.

Latihan empati sangat bermanfaat dilakukan sejak masa kanak-kanak. Walupun demikian tidak terlambat dilakukan latihan empati terhadap individu setelah individu menyadari pentingnya empati terhadap ndividu lainnya yang sedang mengalami permasalahan, terutama ada kaitan dengan kelancaran pelaksanaan tugas sebagai perawat di rumah sakit.

\section{Motif Altruistik Perawat terhadap Pasien di Rumah Sakit}

Motif altruistik perawat dalam memberikan pelayanan terhadap pasien di rumah sakit di Sumatera Barat terlihat pada tabel berikut ini :

Tabel 2 : Motif Altruistik Perawat terhadap Pasien dalam Pelayanan Kesehatan di Rumah Sakit.

\begin{tabular}{|c|c|c|c|c|c|c|}
\hline No & INDIKATOR & SS & SR & $\mathrm{JR}$ & JS & TP \\
\hline 1. & $\begin{array}{l}\text { Memberi } \\
\text { Pertolongan } \\
\text { Dengan Rasa } \\
\text { Senang }\end{array}$ & $64.32 \%$ & $8.20 \%$ & $10.89 \%$ & $3.63 \%$ & $12.94 \%$ \\
\hline 2. & $\begin{array}{l}\text { Memberi } \\
\text { Pertolongan } \\
\text { Dengan Rasa } \\
\text { Puas. }\end{array}$ & $40.59 \%$ & $10.62 \%$ & $27.01 \%$ & $9.44 \%$ & $12.32 \%$ \\
\hline & Jumlah & $39.99 \%$ & $54.52 \%$ & $4.35 \%$ & $3.82 \%$ & $7.27 \%$ \\
\hline
\end{tabular}

Berdasarkan tabel di atas diperoleh keterangan, sebanyak 64,32 \% perawat memberikan pertolongan dengan rasa senang terhadap pasein dalam memerikan pelayanan di rumah sakit.. Selanjutnya sebanyak 10,89 \% perawat jarang , 8,20 \% sering, 12,94\% tidak pernah dan 3,63\% jarang sekali memberi pertolongan dengan rasa senang terhadap pasein dalam memberikan pelayanan di rumah sakit. Dengan demikian sebagian besar perawat telah memberi pertolongan terhadap pasein dengan senang dalam memberikan pelayanan di rumah sakit. Walaupun demikian persaaan senang yang dialami perawat di rumah sakit dalam memberikan pertolongan terhadap pasien belum optimal ( $12,94 \%$ tidak pernah, 10,89 jarang dan 3,63\% jarang sekali memberikan pertolongan dengan senang terhadap pasien dalam memberikan pelayanan di rumah sakit).

Dari segi kepuasan memberikan pertolongan, ditemukan sebanyak 64,32\% sangat sering merasa puas setelah memberikan pertolongan terhadap pasien. 10,89 \% jarang, $12,94 \%$ tidak pernah dan $8,20 \%$ sering merasa puas setelah memberikan pertolongan 
terhadap pasien. Dengan demikian sebagian besar perawat memberikan pelayanan di rumah sakit merasa puas setelah memberikan pertolongan terhadap pasien. Walaupun demikian kepuasan perawat setelah memberikan pertolongan terhadap pasien dalam pemberian pelayanan di rumah sakit belum optimal ( $27,46 \%=10,89 \%$ jarang, 3,63 Jarang sekali dan 12,94 tidak pernah puas setelah memberikan pertolongan terhadap pasien di rumah sakit).

Berdasarkan tabel di atas, secara keseluruhan diperoleh keterangan sebanyak 54,52 $\%$ perawat memiliki motif altruistik dalam memberikan pelayanan terhadap pasien di rumah sakit. Selanjutnya sebanyak 39,99\% sering sekali, 7,27 tidak pernah, 4,35 jarang dan 3,82 jarang sekali memiliki motif altruistik dalam memberikan pelayanan terhadap pasien di rumah sakit Dengan demikian sebagian besar perawat telah memiliki motif altruistik terhadap pasien dalam memberikan pelayanan di rumah sakit. Walaupun demikian motif altruistik perawat terhadap pasien dalam memberikan pelayanan di rumah sakit belum optimal ( $15,44 \%=7,27 \%$ tidak pernah, 4,35 jarang dan 3,82 \% jarang sekali memiliki motif altruistik terhadap pasien dalam memberikan pelayanan di rumah sakit.

Belum optimalnya motif altruistik perawat terhadap pasien di rumah sakit didasari oleh : karakteristik situasi dan karakteristik penolong. Motif altruistik perawat terhadap pasien kurang terwujud secara optimal karena situasi membolehkan keluarga pasien ikut melayani pasien selama perawatan di rumah sakit. Berdasarkan hasil penelitian Bibb dab John Darley (Ruch,198:564) mengemukakan kehadiran penonton yang begitu banyak menjadi alasan tiadanya motivasi memberikan pertolongan. Individu memberi reaksi keadaan darurat dalam kondisi kesendirian, bila mereka mempunyai anggapan bahwa orang lain juga mengetahui situasi tersebut. Semakin banyak orang lain yang hadir, semakin kecil kemungkinan seseorang benar-benar memberi pertolongan dan semakin besar rata-rata rentang waktu pemberian bantuan. Selanjutnya kebanyakan orang hadir menyeabkan situasi tidak jelas.

Selanjutnya jenis kelamin dan intelegensi turut mempengaruhi membantu orang lain. Suasana hati yang baik turut mempengaruhi bantuan terhadap orang lain. Carlso (Myers,1989 : 587) mengungkapkan orang yang suka menolong karena pada saat bahagia mereka menjadi lebih baik hati dan lebih berhasrat untuk menolong. Rasa bahagia yang dialami seseorang terhadap dirinya sendiri dapat mendorong mereka berperilaku altruistik. Apabila kebahagiaan itu ditujukan kepada orang yang membutuhkan, perilaku altruistik sampai tingkat signifikan.

Pengetahuan dan kemampuan menolong secasa efektif merupakan faktor penting yang dapat mempengaruhi kesediaan seseorang menolong orang lain. Sehubungan dengan hal itu latihan yang dilakukan dengan prosedur tertentu, khususnya role playing dapat meningkatkan perilaku prososial. 
Secara umum ditemukan layanan diberikan kepada orang yang menarik dan disukai. Pria lebih banyak menolong wanita yang menarik secara fisik dibandingkan dengan yang tidak.Sehubungan dengan hal itu, jumlah perawat wanita (93\%) yang lebih banyak dari perawat laki-laki turut mewarnai pelayanan yang diberikan kepada pasien jenis kelamin berbeda.

\section{Pengaruh Empati terhadap Motif Altruistik Perawat di Rumah Sakit}

Data motif altruistik telah memenuhi uji asumsi yang diisyaratkan untuk penggunaan analisis regresi, yaitu asumsi normalitas sebaran dan linieritas hubungan antar variabel. Dari hasil penguyjian didapat hasil sebaran normal dan korelasi linier.

Berdasarkan pengujian melalui analisis regresi di atas pengaruh empati terhadap motif altruistik perawat terhadap pasien dalam memberikan pelayanan di rumah sakit, ditemukan F-regresi sebesar 64,229 dengan peluang ralat sebesar 9,351. Hipotesa yang digunakan adalah hipotesis berarah, maka nilai $\mathrm{p}$ dibagi dua sehingga $\mathrm{p}$ menjadi 4,6755. Nilai $p=4,6755$ menunjukan adanya pengaruh yang signifikan dari empati terhadap motif altruitik perawat membantu pasien dalam memberikan pelayanan di rumah sakit. Dengan demikian hipotesis alternatif pengaruh empati terhadap motif altruistik perawat dalam memberikan pelayanan terhadap pasien di rumah sakit diterima dan hipotesis nihil terbukti ditolak.

Korelasi antara empati dengan motif altruistik perawat terhadap pasien dalam memberikan pelayanan di rumah sakit, adalah 0,737 , sedangkan koefisien diterminasinya ( $\mathrm{r}$ 2) sebesar 0,543 . Hal ini menunjukan motif altruistik perawat membantu pasien dalam pelayanan di rumah sakit, dijelaskan oleh empati sebesar 54,3\%. Sedangkan sisanya 45,7 $\%$ dijelaskan oleh variabel lain.

\section{Kesimpulan dan Rekomendasi}

\section{Kesimpulan}

Berdasarkan temuan dan pembahasan penelitian dapat disimpulkan sebagai berikut :

a. Perawat dalam pemberian pelayanan di rumah sakit belum berempati terhadap permasalahan pasien secara optimal.

b. Perawat dalam memberi pelayanan di rumah sakit terhadap pasien belum memiliki motif altruistik secara optimal.

c. Terdapat pengaruh empati terhadap motif altruistik perawat di rumah sakit dalam pemberian pelayanan. Motif altruistik perawat di rumah sakit dalam pemberian pelayanan terhadap pasien dijelaskan oleh empati sebesar 54,3\%. Sedangkan sisanya dijeaskan oleh varibel lain. 
Berdasarkan temuan penelitian, dapat dikemukan saran sebagai berikut :

a. Pelatihan/penataran terhadap perawat kurang efektif menumbuhkan empati dan motif altruistik terhadap pasien. Dinas kesehatan, Rumah Sakit diharapkan bekerjasama dengan Balitbang, Pakar dari Perguruan Tinggi untuk melaksanakan penseleksian peserta, penyusunan kurikulum, penetapan nara sumber serta merumuskan model pelatihan/penataran yang dapat menumbuhkan motif altruistik dan empati perawat.

b. Pemahaman perawat di rumah sakit atas informasi terhadap pasien dan pelayanan masih lemah. Dinas kesehatan, rumah sakit, dirasa perlu meningkatkan kompetensi perawat melalui pelatihan dan kesempatan untuk mengikuti pendidikan lanjutan.

c. Interaksi perawat senior dengan yunior, perawat dengan mahasiswa yang sedang melaksanakan praktek kerja lapangan di rumah sakit terlihat kurang kodusif dalam mengembangkan empati dan motif alruistik terhadap pasien. Rumah sakit dan Jurusan/Prodi Keperawatan dirasa perlu berkoordinasi dalam merevitalisasi pola kerja yang berwawasan kemitraan sesama profesi keperawatan.

d. Komitmen perawat di rumah sakit memberi pelayanan terhadap pasien terasa masih lemah. Dinas Kesehatan dan rumah sakit dirasa perlu merumuskan pola penilaian, melaksanakan reevaluasi terhadap perawat yang sudah bertugas serta menetapkan klasifikasi perawat sesuai dengan potensi yang dimilikinya. Pemberian reward dalam bentuk perawat teladan, kenaikan gaji dan pangkat didasarkan atas penilaian kenerja perawat tersebut pada masing-masing bagian.

e. Monitoring terhadap perawat dalam pemberian pelayanan kepada pasien terlihat masih kurang. Rumah sakit dirasa perlu merumuskan pola dan melaksanakan monitoring secara kontiniu sesuai dengan tugas fungsi keperawat pada masing-masing bagian.

f. Mitra kerja antara dokter dengan perawat belum terwujud secara optimal dalam menumbuhkan empati dan motif altruistik perawat terhada pasien.. Dinas kesehatan, rumah sakit dirasa perlu membangun mitra kerja antara dokter dengan perawat dalam memberikan pelayanan optimal bagi pasien, melalui diskusi, seminar profesional pada setiap bagian secara kontiniu.

g. Hubungan perawat dengan mahasiswa yang sedang praktek kerja di rumah sakit kurang kondusif sehingga tidak mengembangkan empati dan motif altruistik bagi calon-calon perawat terhadap pasien.Jurusan/Prodi Keperawatan, Rumah Sakit dirasa perlu berkoordinasi merevitalisasi pedoman praktek kerja serta pola bimbingan dari perawat senior/dosen pembimbing selama praktek kerja di rumah sakit.

h. Penyusunan laporan dan pelaksanaan tugas perawatan di rumah sakit bersifat rutinitas dan pelayanan perawatan tidak jarang hanya dilakukan oleh mahasiswa sehingga pasien 
merasa diabaikan. Rumah sakit dirasa perlu merumuskan tugas fungsi serta sistem monitoring terhadap perawat yang sedang bertugas memberikan pelayanan kesehatan terhadap pasien.

i. Pengembangan konteks keluarga dalam pemberian asuhan keperawatan bagi paisien di rumah sakit ditemukan telah mengantikan pekerjaan perawat dalam merawat pasien sehingga menghalanggi pengembangan motif altruistik perawat terhadap pasien. Dinas Kesehatan, Rumah sakit dirasa perlu merumuskan pedoman, dan sistem monitoring pengembangan asuhan kesehatan dalam konteks keluarga sehingga pedapingan/kesinambungan perawatan pasien pasca perawatan di rumah sakit dapat terwujud sesuai dengan sasaran yang diinginkan.

j. Koordinasi antar satu bagian dengan bagian lain ditemukan masih lemah dan tidak jarang pasien dan keluarganya merasa diabaikan. Rumah sakit dirasa perlu membangun pola jaringan, sistem informasi antar bagian dalam peningkatan pelayanan terhadap pasien.

k. Kedisiplinan perawat akan penampilan dalam penggunaan simbol-simbol profesi keperawatan masih lemah sehingga membigungkan pasien akan idetitas profesi perawat. Rumah sakit dirasa perlu merumuskan pola penggunaan simbol-simbol keperawatan serta penegakan disiplin perawat untuk memlihara identitas profesi keperawatan.

1. Penegakan etika praktek keperawat terasa masih lemah sehingga tidak membangun situasi pengembangan empati dan motif altruistik perawat terhadap pasien. Dinas Kesehatan dan rumah sakit dirasa perlu merumuskan, menegakan sangsi serta memonitoring atas pelanggaran etika praktek keperawatan di rumah sakit. 


\section{DAFTAR PUSTAKA}

Bernstein, D.A. (1984). Psychology. Third edition. Boston : Houghton Mifflin Company.

Brems, C.,Fromme.D.K.,\& Johnson, M.E. (1982). Group Modification of Empathic Verbalization and Self Disclosure. The Journal of Social Psychology. Vol.132.No.2.189.190-198.

Brodzinsky, Gormly, Ambron, (1986). Lifespan Human Development. Third edition. New York : CBC Company Publishing.

Blocher, Donald H. (1974). Developmental Counseling. New York: John Wiley \& Sons

De Vito, J.A (1990). Mesages-Building Interpersonal Comunication Skill. New York : Harper and Row Publisher.

Houston, D.A, (1990). Empathy and the Self : Cognitif and Emotional Influences on The Evaluation of Negative Affect in Others. Journal of Personality and Social Psychology. Vol.59.No.5.859.860. 867.

Liebert, R.M.,R.W.Poulos, and G.S, Marmor. (1979). Developmental Psychology. Second edition. New Delhi : Prentice-Hall.

M.I.Soelaiman, (1981). Moral, Perilaku Moral dan Perkembangan Moral . Jakarta : Universitas Indonesia.

Ohbuchi, K., Ohno, T., \& Mukai, H, (1993). Empathy and Agression : Effect of Self-disclosure and Fearful Appeal. The Journal of Social Psychology, Vol.133. No.2. 234,244.

Phares, E.J (1984).Introduction to Personality Psychology. New York : Charles E.Merril Publishing Company.

Prayitno, (1987). Profesionalisasi Konseling dan Pendidikan Konselor. Jakarta : Departemen Pendidikan dan Kebudayaan.

Smart, M.S.,and R.C.Smart (1980). Children : Development and Relationship. Third edition. Collier MacMillan.

\section{Curiculum Vitae}

Nama : Dr.Firman.MS. Lahir tanggal 25 Februari 1961 di Nagari Balai Gurah Kecamatan IV Angkat Candung Kabupaten Agam. Menamatkan Pendidikan di SD Negeri Koto Tuo Balai Gurah, SMP Negeri NoVI Bukittinggi, SPG Negeri Bukittinggi, Sarjana Bimbingan Konseling IKIP Padang, Magister Psikologi Sosial Univ.Padjadjaran Bandung dan Doktor Ilmu Sosial Univ.Airlangga Surabaya yang diselesaikan tahun 1997. Sekarang bertugas sebagai Kepala Bidang Kemasyarakatan Balitbang Propinsi Sumatera Barat, Dosen Jurusan Bimbingan dan Konseling FIP Univ.Negeri Padang, Dosen Fakultas Kesehatan Masyarakat Univ. Baiturrahmah Padang serta Dosen Program Pascasarjana Univ.Negeri Padang. 
SUMMARY EXUGUTIUE

\section{PenIngkatan Pelayanan RUmah Sakit}

MELIU ANALSIS EMPATI DAN MOTIF ALTRUISTIK

PERAWAT DI RUMAH SAKIT

Oleh

DR. Firman. MS

Dra. Yenikarneli. M.Pd.

Drs. Erlansyah. M.Pd.

Andi Bastian. SH 


\section{BIDANG KEMASYARAKATAN BALITBANG PROPINSI SUMATERA BARAT 2003}

\section{KATA PENGANTAR}

Kegiatan penelitian merupakan salah satu tugas pokok yang harus dilaksanakan Badan Penelitian dan Pengembangan Propinsi Sumatera Barat dalam membantu Gubernur merumuskan Kebijakan. Kegiatan penelitian ini dilaksanakan oleh Bidang Kemasyarakatan Balitbang Propinsi Sumatera Barat Bekerjasama dengan staf Pengajar Univ. Negeri Padang

Kegiatan penelitian ini diawali oleh penyusunan TOR, proposal, seminar proposal/konsep dan seminar rekomendasi hasil penelitian, yang melibatkan dosen/tenaga peneliti perguruan tinggi di Sumatera Barat, fungsional peneliti serta Birokrat. Walaupun demikian, hasil penelitian ini masih menunjukkan beberapa kelemahan, namun kami yakin hasilnya dapat dijadikan bahan pertimbangan dalami pengambilan kebijakan peningkatan kualitas pelayanan rumah sakit.

Selesainya laporan penelitian ini atas dorongan moril dan materil dari berbagai pihak. Pada kesempatan ini kami mengucapkan terima kasih kepada: Bapak Gubernur Propinsi Sumatera Barat, Bapak Kepala Balitbang Propinsi Sumatera Barat, Bapak Kepala Dinas Pendidikan, Kepala Rumah Sakit M. Djamil dan Rumah Sakit Achmad Muchtar yang telah memberikan kemudahan demi selesainya penelitian ini. Kami yakin tanpa dedikasi dan kerjasama yang baik, penelitian ini tidak dapat diselesaikan. 
Akhirnya penulis mengucapkan terima kasih kepada semua pihak yang telah membantu terwujudnya penelitian ini.

Padang, Desember 2002

Peneliti, 